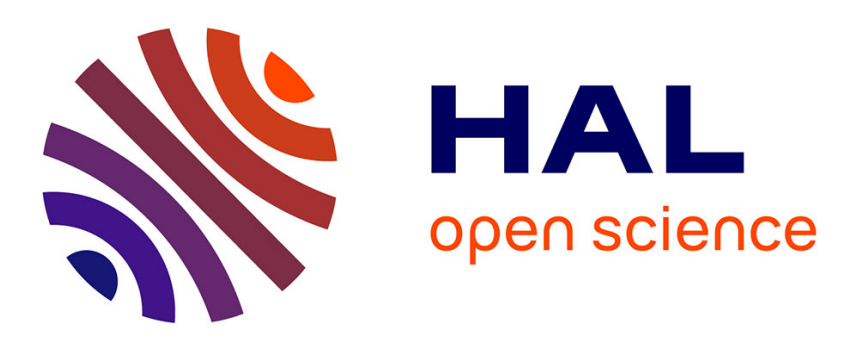

\title{
Torrefaction treatment of lignocellulosic fibres for improving fibre/matrix adhesion in a biocomposite
}

Marie-Alix Berthet, Jean-Michel Commandre, Xavier Rouau, Nathalie Gontard, Helene Angellier-Coussy

\section{- To cite this version:}

Marie-Alix Berthet, Jean-Michel Commandre, Xavier Rouau, Nathalie Gontard, Helene AngellierCoussy. Torrefaction treatment of lignocellulosic fibres for improving fibre/matrix adhesion in a biocomposite. Materials \& Design, 2016, 92, pp.223-232. 10.1016/j.matdes.2015.12.034. hal01269460v1

\section{HAL Id: hal-01269460 \\ https://hal.science/hal-01269460v1}

Submitted on 28 May 2020 (v1), last revised 26 Feb 2016 (v2)

HAL is a multi-disciplinary open access archive for the deposit and dissemination of scientific research documents, whether they are published or not. The documents may come from teaching and research institutions in France or abroad, or from public or private research centers.
L'archive ouverte pluridisciplinaire HAL, est destinée au dépôt et à la diffusion de documents scientifiques de niveau recherche, publiés ou non, émanant des établissements d'enseignement et de recherche français ou étrangers, des laboratoires publics ou privés. 


\title{
Accepted Manuscript
}

Torrefaction treatment of lignocellulosic fibres for improving fibre/matrix adhesion in a biocomposite

\author{
M.-A. Berthet, J.-M. Commandré, X. Rouau, N. Gontard, H. Angellier-Coussy \\ PII: \\ S0264-1275(15)30893-5 \\ DOI: \\ doi: 10.1016/j.matdes.2015.12.034 \\ Reference: \\ JMADE 1058
}

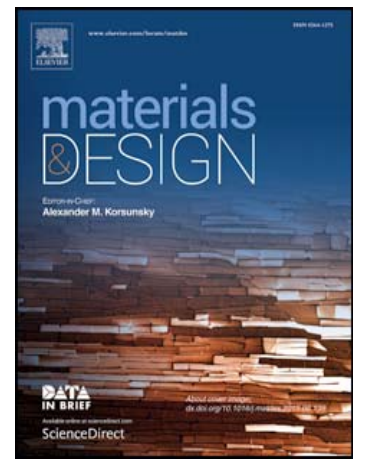

To appear in:

Received date: 23 September 2015

Revised date: $\quad 30$ November 2015

Accepted date: 8 December 2015

Please cite this article as: M.-A. Berthet, J.-M. Commandré, X. Rouau, N. Gontard, H. Angellier-Coussy, Torrefaction treatment of lignocellulosic fibres for improving fibre/matrix adhesion in a biocomposite, (2015), doi: 10.1016/j.matdes.2015.12.034

This is a PDF file of an unedited manuscript that has been accepted for publication. As a service to our customers we are providing this early version of the manuscript. The manuscript will undergo copyediting, typesetting, and review of the resulting proof before it is published in its final form. Please note that during the production process errors may be discovered which could affect the content, and all legal disclaimers that apply to the journal pertain. 


\title{
Torrefaction treatment of lignocellulosic fibres for improving fibre/matrix adhesion in a biocomposite
}

\author{
M-A. Berthet ${ }^{1}$, J.-M. Commandré ${ }^{2}$, X. Rouau ${ }^{1}$, N. Gontard ${ }^{1}$, H. Angellier-Coussy ${ }^{1 *}$ \\ ${ }^{1}$ Unité Mixte de Recherche « Ingénierie des Agropolymères et Technologies Emergentes », \\ INRA/Montpellier Supagro /CIRAD/Université Montpellier, 2 place Viala, 34060 Montpellier, France. \\ ${ }^{2}$ CIRAD, Biowooeb Research Unit, 73 avenue Jean-François Breton, 34398 Montpellier Cedex 5, France \\ *Corresponding author: helene.coussy@univ-montp2.fr, tel : +33(0)4 99612432
}

\begin{abstract}
New PHBV/wheat straw fibres biocomposites were produced in such a way to improve the fibre/matrix interface and modulate functional properties of materials. A torrefaction treatment was applied to wheat straw fibres in such a way to increase their hydrophobicity. This improvement led to a better fibre/matrix interfacial adhesion in resultant composites prepared by melt-extrusion, as revealed by SEM observations. The crystallisation process was favoured by the presence of torrefied fibres while molecular weight and crystallinity of matrix polymers remained unchanged as compared to untreated fibres. Fibre torrefaction treatment had no significant effect on the mechanical properties of PHBV/wheat straw fibres composites, except for $30 \mathrm{wt} \%$ of torrefied fibres with materials displaying an increased rigidity. It was concluded that improving fibre/matrix adhesion and increasing fibre aspect ratio did not lead to a better preservation of mechanical properties, due to the inevitable presence of microscopic defects in the composite materials. As regards water vapour permeability (WVP), a 30\% decrease was first noticed with torrefied fibre contents up to $20 \mathrm{wt} \%$, which was ascribed to the hydrophobic nature of fibres and improvement of fibre/matrix adhesion. WVP then increased for a fibre content of $30 \mathrm{wt} \%$, probably due to the creation of percolating pathway.
\end{abstract}

Keywords

Biocomposite, torrefaction, $\mathrm{PHBV}$, wheat straw, mechanical properties, water vapour permeability. 


\section{Introduction}

In search of new eco-friendly materials, lignocellulosic fibres were widely studied as potential reinforcing fillers in polymer matrices [1], due to their many advantages such as wide availability, low price, density and abrasion towards processing equipments [2]. One recurrent problem of lignocellulosic fibres-polymer composites is the poor affinity between fibres and matrix owing to the intrinsic hydrophobicity of most polymers that contrasts with the hydrophilicity of lignocellulosic fibres. Three main different strategies are possible to promote wettability and intimate contact between the fibre and the matrix, i.e. the fibre surface modification to increase their surface free energy and particularly their hydrophobicity, the polymer matrix modification to increase its hydrophilicity, or the introduction of amphiphilic compatibilizers [3-7]. The most largely used are solvent-based chemical treatments of fibres such as alkali treatments or grafting of coupling agents, which raises the question of environmental impact. Physical and solvent-free treatments have gained more prominence, providing a more "greener" alternative. Physical treatments lead to changes in structural and surface properties of the fibre, while the chemical composition can be modified (in the case of steam explosion process or electric discharge treatments such as corona, sputtering or cold plasma) or not (i.e. stretching or calendaring).

Torrefaction is a well-known process, especially in coffee industry, which consists in a moderate thermal treatment $\left(200-300^{\circ} \mathrm{C}\right)$ of the biomass under an inert atmosphere. It has received attention in the recent years to upgrade the fuel properties of biomass. Indeed, torrefaction has been proven to improve biomass grindability, leading to a better availability for enzymatic digestion [8-12]. Torrefied biomass becomes darker and brittle, due to the loss of its tenacious and fibrous nature resulting from the decomposition of hemicelluloses and partial depolymerisation of lignin and cellulose. Another consequence is the increase in its hydrophobicity, which could be positively exploited for reinforcing applications. To our knowledge, torrefaction was never applied to fibres preparation for composites applications. This treatment is here considered for hydrophobising wheat straw fibres, in an effort to compatibilise these fibres with poly(hydroxybutyrate-co-valerate) (PHBV).

PHBV is a biodegradable bacterial copolyester, reported to be produced from food industry by-products [13]. It displays acceptable mechanical properties despite its tendency to brittleness, exacerbated when mixed with fibres for composite applications. Wheat straw is a by-product of wheat cultivation produced in large quantities throughout the world and still underutilized in many countries. Combination of these two components has been studied previously to produce full biocomposites [14-17], and the occurrence of a poor fibre/matrix adhesion was identified as a key parameter governing final composite structure and functional properties (mechanical and water vapour transfer) [16-17]. Torrefaction of wheat straw fibres has been already studied, as a preparation step for enzymatic digestion, aiming biofuel production [18-19]. 
No obvious structural change occurred in wheat straw below $200{ }^{\circ} \mathrm{C}$. At $300{ }^{\circ} \mathrm{C}$, hemicellulose and cellulose contents of torrefied wheat straw were very low, in comparison to lignin, which becomes the major constituent of torrefied wheat straw. No data about the evolution of torrefied wheat straw fibre hydrophobicity was reported, and no application in the field biocomposites has been yet tested.

The objective of this study is to design new biocomposites by exploring for the first time the impact of a solvent-free treatment, i.e. torrefaction of wheat straw fibres, on the final functional properties of PHBVbased composite materials for food packaging applications. For that purpose, the impact of torrefaction on fibre characteristics (composition, morphology and surface state) was first assessed towards different conditions of temperature and duration. Then, torrefied wheat straw fibres, prepared according to optimized conditions of temperature and duration, were mixed with PHBV by extrusion to prepare composite materials with increasing filler contents. The resulting functional properties (mechanical properties and water vapour permeability) of composite materials were assessed and discussed in relation to their multi-scale structure while keeping in mind the point of view of food packaging applications.

\section{Materials and methods}

\subsection{Raw materials}

A commercial PHBV (injection molding grade) with $3 \mathrm{~mol} \%$ valerate content was purchased from Tianan Biologic Materials Company (ENMAT ${ }^{\mathrm{TM}}$ Y1000P). Pellets were dried overnight at $60{ }^{\circ} \mathrm{C}$ before processing. Wheat straw (Triticum aestivum $c v$. Apache) was kindly provided by Fernand Meaux (Saint Jean du Salés, Tarn, France).

\subsection{Preparation and characterization of wheat straw fibres}

\subsubsection{Preparation of wheat straw fibres}

Grinding and sorting. Wheat straw fibres were prepared as described in the work of Silva et al. (2011). Briefly, wheat straw (stored at room temperature and relative humidity and with a moisture content of 8 wt\% w.b.) was preliminary reduced using a cutting mill type SM2000 (Retsch, Germany) with a $4.0 \mathrm{~mm}$ sieve. Fibre were then let to dry overnight at $60^{\circ} \mathrm{C}$ and afterwards ground on an impact mill type $100 \mathrm{UPZ}$ (Hosokawa Alpine, Germany) operated at $18000 \mathrm{rpm}$ and equipped with a $0.3 \mathrm{~mm}$ selection sieve (trapezoid holes), a 8-teeth rotor and an output recovery by cyclone. Sorting of fibres, previously dried overnight at $60{ }^{\circ} \mathrm{C}$, took place in an air-classifier 100 AFG from Hosokawa Alpine, $G E$, by setting the feeder rate at $360 \mathrm{~g} . \mathrm{h}^{-1}$, the selector speed at $6000 \mathrm{rpm}$ and the pressure at -5 bars. Only the resultant coarse fraction, was kept, and will be referred as WSF. 
Torrefaction. Preliminary exploration of torrefaction conditions were performed on a horizontal tubular oven (Pyrolab). Objectives of these tests are to produce several grams of torrefied wheat straw in a large range of operating conditions. Sample was first placed in a cool zone of the oven (cooled at room temperature) during the $\mathrm{N}_{2}$ sweeping, ensuring the experiment takes place without oxygen. Ten minutes after, sample was moved towards the hot zone of the oven and heated at the targeted temperature for the duration of the experiment. The residence time of the torrefaction process starts when the material has reached the set temperature. The sample was then moved back to the cool zone in order to stop the reaction and to let it cool under inert atmosphere, and finally gathered and weighted. Torrefaction was carried out at 180,230 and $280{ }^{\circ} \mathrm{C}$ with residence time of $45 \mathrm{~min}$. Additional conditions were tested, including a longer residence time at low temperature $\left(90 \mathrm{~min}\right.$ at $\left.180{ }^{\circ} \mathrm{C}\right)$ and a shorter residence time at high temperatures $\left(15 \mathrm{~min}\right.$ at 230 and $\left.280{ }^{\circ} \mathrm{C}\right)$. Codifications are given in Table 2. «Flash» torrefactions of $15 \mathrm{~min}$ were also tested for the two highest temperatures $\left(230\right.$ and $\left.280^{\circ} \mathrm{C}\right)$ and compared to a long torrefaction duration at low temperature, i.e. $90 \mathrm{~min}$ at $180{ }^{\circ} \mathrm{C}$.

Torrefaction in a medium sized reactor was performed to produce approximately $500 \mathrm{~g}$ of torrefied fibres for further composite processing, at $230^{\circ} \mathrm{C}$. Reactor containing the sample was placed in an oven and swept with a $30 \mathrm{~L} \cdot \mathrm{min}^{-1} \mathrm{~N}_{2}$ flow in order to ensure inert, then torrefaction occurred under a $10 \mathrm{~L} \cdot \mathrm{min}^{-1} \mathrm{~N}_{2}$ flow. Torrefaction duration (45 min) was counted from the moment temperature reached $230{ }^{\circ} \mathrm{C}$ in the bulk of the sample. At the end of torrefaction duration, the closed reactor was removed from oven and let to cool at room temperature, still under $\mathrm{N}_{2}$ flow.

\subsubsection{Characterization of wheat straw fibres}

Thermogravimetric analysis. Thermogravimetric analysis (TGA) was carried out by using a TGA Q50 W/MFC apparatus of TA Instruments. Samples (about $10 \mathrm{mg}$ ) were heated from room temperature up to $700^{\circ} \mathrm{C}$ under nitrogen flow $\left(60 \mathrm{~mL} \cdot \mathrm{min}^{-1}\right)$, at a heating rate of $10{ }^{\circ} \mathrm{C} \cdot \mathrm{min}^{-1}$ and weight variation was measured over time. The thermal degradation was characterized by three temperatures: (i) the temperature corresponding to the beginning of the degradation process, i.e. at which the absolute value of the first derivative of the weight loss became higher than $0.1 \% /{ }^{\circ} \mathrm{C}\left(\mathrm{T}_{\text {onset }}\right)$, (ii) the temperature at which the degradation rate was maximum ( $\mathrm{T}_{\text {peak }}$ ) and (iii) the temperature corresponding to the end of the degradation process, i.e. at which the absolute value of the first derivative of the weight loss became lower than $0.1 \% /{ }^{\circ} \mathrm{C}\left(\mathrm{T}_{\text {offset }}\right)$. Experiments were performed in duplicate.

Fibre composition. Composition was analysed with a protocol already published (Barakat et al., 2014). Briefly, the carbohydrate composition of lignocellulosic samples was measured as sugars using highpressure liquid chromatography (HPLC) after two sulphuric acid hydrolyses $\left(26 \mathrm{~N}\right.$ at $25{ }^{\circ} \mathrm{C}$, then $2 \mathrm{~N}$ at 
$100{ }^{\circ} \mathrm{C}$ ) followed by filtration. The lignin content in samples was determined by the Klason method, as described by Monties [20]. All the determinations reported here were means of duplicate results.

Fibre morphology. Morphological characterization of wheat straw fibres was carried out by image analysis of optical microscopic observations, as deeply described in the work of Montaño-Leyva et al. [21]. Morphological analysis enabled to evaluate fibre equivalent diameter, expressed as equivalent diameter, which is the diameter of a circumference with the same area, and elongation, defined by max Feret diameter (maximum axis inside the particle) divided by equivalent rectangle short side.

Fibre surface free energy. Fibre surface free energy was assessed by contact angle measurements, as already described by Montaño-Leyva et al. [21]. The dispersive $\left(\begin{array}{c}d \\ S\end{array}\right)$ and polar $\left(\begin{array}{c}p \\ S\end{array}\right)$ components of the solid surface tension were evaluated by applying the Owens-Wendt approach [22] by using four reference liquids, i.e. distillated water, diiodomethane (Acros organics, Geel, Belgium), ethylene glycol (Aldrich chemical Co. Inc., Milwaukee, USA) and glycerol (Merk, Darmstadt, Germany).

Dynamic Vapour Sorption. Moisture sorption kinetics experiments were performed at $20^{\circ} \mathrm{C}$ using a controlled atmosphere microbalance (Dynamic Vapour Sorption (DVS) apparatus; Surface Measurement System Ltd., London, UK) as previously described in the literature [23]. The DVS apparatus enables recording of the mass evolution with time as a function of relative humidity of the air in contact with the sample. In practice, successive relative humidity steps (from $0 \%$ to $95 \%$, with $10 \%$ step up to $90 \%$ and $5 \%$ step beyond) were performed for a same sample and the remoistening kinetic was followed step by step until equilibrium between material and surrounding atmosphere was reached. Moisture sorption isotherms were determined from the equilibrium moisture contents at each relative humidity step. Tests were performed in duplicate.

\subsection{Preparation and characterization of $\mathrm{PHBV} /$ wheat straw fibres composite films}

\subsubsection{Preparation of composites}

Despite all this study is based on the same PHBV grade from Tianan Biologic Materials Company (ENMAT $\left.^{\mathrm{TM}} \mathrm{Y} 1000 \mathrm{P}\right)$, two batches have been used, thus control samples were prepared for each batch group: one for non-torrefied fibres-based composites (noted PHBV (control)), and the second for torrefied fibres-based composites (noted PHBV (control WST-t)).

Compounding. Composite were prepared by melt extrusion in a lab-scale twin-screw extruder with a L/D $=40$ and a screw diameter of $16 \mathrm{~mm}$ (Eurolab from ThermoFisher Scientific) by using raw PHBV pellets and lignocellulosic fibres previously dried at $70{ }^{\circ} \mathrm{C}$ for at least 8 hours. A single screw volumetric feeder, 
$16 \mathrm{~mm}$ (ThermoFisher Scientific) and a gravimetric mini twin feeder (Brabender) were used, respectively for the polymer pellets and the wheat straw fibres. The temperature profile from the polymer feeding to the die varied from $180{ }^{\circ} \mathrm{C}$ to $160{ }^{\circ} \mathrm{C}$ and the rotation speed of the screws was set to $300 \mathrm{rpm}$. A rod die was adapted at the end of the barrel and the obtained solid string was then pelletized with a 2 to $3 \mathrm{~mm}$ length. Resulting compounds were dried at $60{ }^{\circ} \mathrm{C}$ for at least 8 hours.

Shaping. Composite films (about $250 \mu \mathrm{m}$ thick) were obtained by using a heated hydraulic press (PLM 10 T, Techmo, Nazelles, France). Compound pellets, obtained by extrusion, were first heated during 5 min at $170{ }^{\circ} \mathrm{C}$ and then thermo-moulded between two Teflon-coated plates for $5 \mathrm{~min}$ at $150 \mathrm{bar}$ and $170{ }^{\circ} \mathrm{C}$. All composite films were stored in dessicators containing silicagel (around $0 \% \mathrm{RH}$ ) at $20^{\circ} \mathrm{C}$. The average thickness of each produced film (stored in dry conditions) was determined at room temperature with a hand-held digital micrometre (Mitutoyo instruments) from 10 measurements randomly taken over the film surface.

\subsubsection{Characterisation of composites}

Scanning Electron Microscopy. Scanning Electron Microscopy (SEM) observations were performed using a scanning electron microscope (SEM S-4500, Hitachi, Japan) with an acceleration voltage of $2 \mathrm{kV}$ and a detector for secondary electrons. For the observations of cryo-fractured surfaces, films were previously frozen under liquid nitrogen, then fractured, mounted and coated with gold/palladium on an ion sputter coater.

Contact angle measurements. The surface free energy of PHBV was evaluated from contact angle measurements on films, as described for fibres. The work of adhesion $\left(\mathrm{W}_{12}\right)$ between the PHBV-based matrix $\left(\gamma_{1}\right)$ and lignocellulosic fibres $\left(\gamma_{2}\right)$ was estimated by using the following harmonic-mean equation:

$$
W_{12}=\frac{4 \gamma_{1}^{d} \gamma_{2}^{d}}{\gamma_{1}^{d}+\gamma_{2}^{d}}+\frac{4 \gamma_{1}^{p} \gamma_{2}^{p}}{\gamma_{1}^{p}+\gamma_{2}^{p}}
$$

Then, the interfacial tension $\left(\gamma_{12}\right)$ was calculated using eq. 2 :

$$
\gamma_{12}=\gamma_{1}+\gamma_{2}-\mathrm{W}_{12}
$$

Molecular weight analysis. Molecular weight was measured through Gel permeation Chromatography (GPC). Samples for GPC analysis were prepared by dissolving $25 \mathrm{mg}$ of PHBV-based material in $5 \mathrm{~mL}$ of chloroform, in a closed tube, under stirring, at $50^{\circ} \mathrm{C}$. Samples containing fibres were filtered on a $45 \mu \mathrm{m}$ pores filter (VWR, filter paper, qualitative 413), then, all samples were filtered on Macherey-Nagel CHROMAFIL syringe filter (O-20/15 MS type), with pores' size of $0.2 \mu \mathrm{m}$. Molecular weight 
distributions were analysed by gel permeation chromatography (GPC) using a Waters GPC with a differential refractive index detector (Waters 410) and a $600 \mathrm{~mm}$ column PL gel MixC $5 \mu \mathrm{m}$. Chloroform was used as eluent at $1 \mathrm{~mL} \cdot \mathrm{min}^{-1}$ and $20 \mu \mathrm{L}$ of sample solution were injected. Calibration of the GPC equipment was carried out with polystyrene standards (Polymers Laboratories standards, peak molecular weight range 580-2,470,000 g. $\mathrm{mol}^{-1}$ ).

Differential Scanning Calorimetry. Differential scanning calorimetry (DSC) was used to measure the crystallization \& melting temperatures (respectively $\mathrm{T}_{c}$ and $\mathrm{T}_{\mathrm{m}}$ ) and the crystallinity of PHBV-based materials. Prior to analysis films were conditioned at $53 \% \mathrm{RH}$ over a saturated salt solution of $\mathrm{Mg}\left(\mathrm{NO}_{3}\right), 6 \mathrm{H}_{2} \mathrm{O}$ to be in the same conditions as those used for tensile tests (section 2.3.10). Around $12 \mathrm{mg}$ of material were placed in aluminum pans (Tzero Aluminium Hermetic pan, TA Instruments New Castle, USA) and hermetically sealed. Measurements were done with a thermo-modulated calorimeter (Q200 modulated DSC, TA Instruments, New Castle, USA). Each sample was first heated to $200^{\circ} \mathrm{C}$, then cooled at $10^{\circ} \mathrm{C} \cdot \mathrm{min}^{-1}$ until temperature reached $-40^{\circ} \mathrm{C}$, and finally heated from $-40^{\circ} \mathrm{C}$ to $200^{\circ} \mathrm{C}$ at a heating rate of $10^{\circ} \mathrm{C} \cdot \mathrm{min}^{-1}$. The resultant thermogram displays the variation of Heat Flow per gram of sample (W.g ${ }^{-1}$ ) towards temperature $\left({ }^{\circ} \mathrm{C}\right)$. From this thermogram, $\mathrm{T}_{\mathrm{c}}$ and $\mathrm{T}_{\mathrm{m}}$ are measured respectively from peaks tops of the cooling ramp and $2^{\text {nd }}$ heating ramp. Melting enthalpy $\left(\Delta \mathrm{H}_{\mathrm{m}}\right)$ is calculated from the area under the peak observed on $2^{\text {nd }}$ heating ramp $(A)$, with a correction regarding the real wheat straw ratio $(\% \mathrm{WS})$ calculated from TGA analysis, with the equation:

$$
\Delta \mathrm{H}_{\mathrm{m}}=A /(100-\% \mathrm{WS})
$$

Crystallinity $\left(\mathrm{X}_{\mathrm{c}}\right)$ of each sample was calculated from $\Delta \mathrm{H}_{\mathrm{m}}$ with the equation:

$$
\mathrm{X}_{\mathrm{c}}=\left(\Delta \mathrm{H}_{\mathrm{m}} / \Delta \mathrm{H}_{\mathrm{m}}^{*}\right) \times 100
$$

where $\Delta \mathrm{H}_{\mathrm{m}}$ is the apparent fusion enthalpy and $\Delta \mathrm{H}_{\mathrm{m}} *$ the theoretical fusion enthalpy of a $100 \%$ crystalline polymer. A value of $146 \mathrm{~J}_{\mathrm{g}} \mathrm{g}^{-1}$, for $\Delta \mathrm{H}_{\mathrm{m}}$ * of PHBV was used. This value, found for PHB homopolymer by Barham et al. [24] is considered as a good approximation of the $\Delta \mathrm{H}_{\mathrm{m}}{ }^{*}$ for PHBV samples, provided that the copolymers have a low percentage of hydroxyvalerate units.

Tensile tests. The mechanical properties of the different materials were evaluated trough tensile tests dumbbell shaped specimens ( $4 \mathrm{~mm}$ wide) die-cut from both hot-pressed sheets $(0.25 \mathrm{~mm}$ thick) using a tensile testing machine (Zwick BZ2.5/TN1S, France). Prior to testing, films previously stored in desiccators at $20{ }^{\circ} \mathrm{C}$ and $53 \% \mathrm{RH}$ (over a $\mathrm{MgNO}_{3}$ saturated salt solution). Nominal stress at break $\left(\sigma_{b}\right)$, nominal strain at break $\left(\varepsilon_{b}\right)$ and Young's modulus $(E)$ were determined from force-elongation curves. The 
energy for the rupture was calculated from the total area under the curve of the force (in $\mathrm{N}$ ) as a function of the elongation (in $\mathrm{mm}$ ). Ten specimens of each sample were tested at a cross-head speed of $10 \mathrm{~mm} . \mathrm{min}^{-}$ ${ }^{1}$ and an initial grip distance of $45 \mathrm{~mm}$.

Water vapour permeability. Water vapour transmission rate (WVTR) of films $\left(\mathrm{g} \cdot \mathrm{m}^{-2} \cdot \mathrm{day}^{-1}\right)$ was gravimetrically determined at $20{ }^{\circ} \mathrm{C}$ using a modified ASTM procedure. Samples (discs of $40 \mathrm{~mm}$ diameter) were hermetically sealed (with Teflon seals) in a glass permeation cell containing distilled water. The permeation cell was placed at $20^{\circ} \mathrm{C}$ in a desiccator containing silicagel, thus obtaining a $\mathrm{RH}$ gradient equal to $0-100 \%$ (i.e. $\Delta P=2338 \mathrm{~Pa}$ at $20{ }^{\circ} \mathrm{C}$, assuming that the $\mathrm{RH}$ on the silicagel is negligible). The water vapour transfer through the exposed film area $\left(9.08 \mathrm{~cm}^{2}\right)$ was measured from the cell weight loss as a function of time. Cells were weighed using a four-digit balance regularly over a 10 days period, after steady-state vapour flow had been reached. At least three samples of each type of film were tested and WVTR was calculated from the following equation:

$$
W V T R=\frac{w}{A} \quad(\text { Eq. } 5)
$$

where $w$ is the slope of the weight loss versus time, $\left(\right.$ g.day $\left.^{-1}\right), A$ is the area of exposed film $\left(\mathrm{m}^{2}\right)$.

Water vapour permeability (WVP) values, expressed in mol.m. $\mathrm{s}^{-1} \cdot \mathrm{Pa} \cdot \mathrm{m}^{-2}$, were deduced from WVTR measurements.

\section{Results and discussion}

\subsection{Impact of torrefaction on fibre characteristics}

Torrefaction was used to prepare wheat straw fibres with an increased hydrophobicity, but other aspects should also be kept in mind. First, to preserve the cheap cost of wheat straw fibres, high yield should also be aimed. Secondly, fibre intrinsic properties such as mechanical properties and aspect ratio should also be preserved as far as possible, due to their impact on resultant functional properties of composites.

In a preliminary study, aimed at selecting the best preparation protocol to get fibres addressing those criteria, torrefaction of fibres was conducted at $180{ }^{\circ} \mathrm{C}, 230{ }^{\circ} \mathrm{C}$ and $280{ }^{\circ} \mathrm{C}$. To understand the choice of those temperatures, a look must be taken on the behaviour of wheat straw fibres during their thermal degradation under inert atmosphere (Figure 1). Thermal degradation of wheat straw fibres under inert atmosphere is characterized by one main weight loss around $315^{\circ} \mathrm{C}$, with an onset temperature of $135^{\circ} \mathrm{C}$ and an offset temperature of $380^{\circ} \mathrm{C}$. A second weight loss, very less defined, occurs around $450^{\circ} \mathrm{C}$, and the curve flatly decreases until $700{ }^{\circ} \mathrm{C}$ - end of the experiment - leaving a residue of $22 \mathrm{wt} \%$. The first 
weight loss, around $100{ }^{\circ} \mathrm{C}$ and observed for several lignocellulosic fibres, was ascribed to residual water [19].

\section{Figure 1.}

Torrefaction induces an inert thermal degradation of the fibres, which will affect their composition and lead to weight loss. The thermal degradation of lignocellulosic constituents, i.e. cellulose, lignin and hemicellulose, was studied by Chen et al. [25]. The main peaks of thermal degradation, around $275^{\circ} \mathrm{C}$ to $378^{\circ} \mathrm{C}$, depending on botanical source, were ascribed to hemicellulose and cellulose while the degradation of lignin was more progressive and finished during a second weight loss around $450^{\circ} \mathrm{C}$ [25]. When a quicker TGA ramp was applied, i.e. $80^{\circ} \mathrm{C} \cdot \mathrm{min}^{-1}$, weight losses tend to shift to lower temperatures [19]. In that case, hemicellulose and lignin started degrading around $200^{\circ} \mathrm{C}$, whereas cellulose degraded later, in one sharp weight loss around $350^{\circ} \mathrm{C}$. Nevertheless, lignin weight loss was much flatter than for the other constituents, and had a total of only $60 \%$ weight loss at $800^{\circ} \mathrm{C}$ (vs. 70 and $90 \%$ for hemicellulose and cellulose respectively). Thus, at temperatures higher than $350^{\circ} \mathrm{C}$, lignin is better preserved than cellulose and hemicellulose. Nevertheless, if the co-torrefaction of those constituents revealed no synergistic effects for Chen et al. [25], Pasangulapati et al. [19] concluded to catalysis reactions between the different constituents, leading to a coupling of cellulose and hemicellulose degradations, and to accentuated lignin degradation.

In the case of wheat straw, it was previously shown by thermogravimetric analysis coupled with FTIR analysis that below $200^{\circ} \mathrm{C}$ there was no obvious structural change (Shang et al., 2012). At 200-250 ${ }^{\circ}$, hemicelluloses started to decompose, while cellulose and lignin began to decompose at about $270-300^{\circ} \mathrm{C}$ [18].

Three temperatures have been identified on Figure 1: $180^{\circ} \mathrm{C}$, located on the curve's plateau before the main weight loss; $280^{\circ} \mathrm{C}$, still above $50 \mathrm{wt} \%$ of weight loss, but just before degradation temperature peak; and in between, $230^{\circ} \mathrm{C}$, which marks the inflexion of the main weight loss curve. These three temperatures matched respectively $7 \mathrm{wt} \%, 14 \mathrm{wt} \%$ and $10 \mathrm{wt} \%$ of weight loss. Hence, slight thermal degradations are expected, inducing changes in fibre composition, but a high yield will be preserved. Regarding the residence time of torrefaction, $45 \mathrm{~min}$ was selected as the reference duration.

Yield and composition. Table 1 sums up the values of fibre weight recovery after treatment in the torrefaction reactor. The impact of torrefaction temperature was more marked than the impact of duration, except for $280^{\circ} \mathrm{C}$, where the yield decreased when duration increased. The higher the torrefaction temperature, the more mass is lost, until temperature reaches $280^{\circ} \mathrm{C}$, for which around half of the material is lost. Such weight loss is much higher than observed on TGA results for the same temperature. This is 
due to the torrefaction protocol, which introduces the sample in a chamber already equilibrated at the target temperature, whereas TGA reaches it through a ramp. Chen et al. [25], studying the co-torrefaction of hemicellulose, cellulose and lignin, also observed a weight loss shifted to lower temperatures when applying an isotherm. Therefore, the yields observed for $280^{\circ} \mathrm{C}$-torrefied wheat straw is equivalent in terms of weight loss to a higher temperature on TGA weight loss curve, i.e. $317^{\circ} \mathrm{C}$ and $327^{\circ} \mathrm{C}$ for 15 and 45 min of treatment duration, respectively.

\section{Table 1.}

Regarding the composition of wheat straw fibres (Figure 2 and Table 2), they are mainly constituted of cellulose, lignin and hemicelluloses. Ashes are also present in a modest part $(5.3 \pm 0.4 \mathrm{wt} \%)$. Ashes, by nature, are assumed to remain unaffected by torrefaction, which was confirmed by Shang et al. [18]. Their content in each torrefied fraction was thus deduced from untreated WSF's. Unanalysed constituents include proteins, waxes and/or fats, and are referred to as "others".

Normalised composition of each constituent proportion within each fibre type is given in Table 2 . Composition of WSF, WSF-t1 to WSf-t4 were quite equivalent, though their constituents evolution was difficult to assess as wide standard deviations are masking any variation of cellulose, lignin and "others" contents. Nevertheless, the drastic cellulose degradation in $280^{\circ} \mathrm{C}$-torrefied fibres led to a high lignin content within WSF-t5 and WSF-t6. The global weight loss, while the ash quantity remained unaffected, led also to indirectly increase the ash content in $280^{\circ} \mathrm{C}$-torrefied fibres. As observed for yield values, torrefaction duration had less effect on fibre composition than torrefaction temperature, while the most marked impact was observed for $280^{\circ} \mathrm{C}$.

The correlation of composition and yield results allowed to explain the degradation behaviour of wheat straw during torrefaction. The 6-7 wt $\%$ weight loss of $180^{\circ} \mathrm{C}$-torrefied fibres (WSF-t1 \& WSF-t2) (Table 1) was ascribed to removal of residual water (even after drying) and low molecular weight aromatic compounds, and beginning of lignin degradation [19]. The $18 \mathrm{wt} \%$ weight loss of $230^{\circ} \mathrm{C}$-torrefied fibres (WSF-t3 \& WSF-t4) (Table 1) was ascribed to the degradation of lignin and hemicellulose, but also of other constituents (proteins, waxes and/or fat) (Figure 1). The drastic weight loss observed for $280^{\circ} \mathrm{C}$ torrefied fibres, i.e. 48 and $55 \mathrm{wt} \%$ for WSF-t5 \& WSF-t6 respectively, was explained by the almost complete degradation of cellulose, as only 2 to $10 \mathrm{wt} \%$ remained from its initial quantity. Such results are corroborating the values published by Shang et al. [18], who reported contents of $98.40 \mathrm{wt} \%$ d.b. lignin, $1.02 \mathrm{wt} \%$ d.b. cellulose and $0.34 \mathrm{wt} \%$ hemicellulose (ash free basis) for a $300^{\circ} \mathrm{C}$ and 2 hours torrefaction treatment.

\section{Table 2.}


Fibre colour. The colour of fibres was also affected by torrefaction, with a colour evolving from light cream for WSF, through light brown and dark brown for both $180^{\circ} \mathrm{C}$-torrefied samples (WSF-t1 \& WSFt2) and both $230^{\circ} \mathrm{C}$-torrefied samples (WSF-t1 \& WSF-t2) respectively, to black for both $280^{\circ} \mathrm{C}$-torrefied samples (WSF-t5 \& WSF-t6). The visual aspect was quantitatively confirmed by the (L*,a*,b*) values (Figure 2). $\mathrm{L}^{*}$, theoretically varying from 0 (black) to 100 (white) and representing the lightness, decreased from 70 for untreated WSF down to 42 for the most drastic torrefaction treatment, meaning that torrefaction led to darker particles. $a^{*}$, representing the red/green opponent and ranging from positive (red) to negative (green) values trough zero (gray), decreased from 9.1 down to 2.3, meaning that the colour tended towards the red. At the same time, $b^{*}$, representing the yellow/blue opponent and ranging from positive (yellow) to negative (blue) values trough zero (gray), decreased from 17.9 down to -2.9, meaning that the colour tended to gray. As for yield and composition, the colour was strongly affected by the temperature, but not by the torrefaction residence time. Mild changes in colour of WSF-t1 to WSF-t4 samples were attributed to the Maillard reaction due to the presence of reduced sugars and amino acids, and also to the possible oxidation of phenolic compounds, and/or caramelization processes of holocellulose [26]. WSF-t5 \& WSF-t6 darkened colour could also be related to carbonisation of lignocellulosic material.

\section{Figure 2.}

Morphology. Since it was demonstrated that residence time had no significant impact on torrefied fibre composition, yield and colour, a torrefaction duration of $45 \mathrm{~min}$ was chosen for further morphological analysis.

Morphological analysis enabled to evaluate fibre's equivalent diameter, which is the diameter of a circumference with the same area, as well as elongation, defined as the ration between the max Feret diameter (maximum axis inside the particle) divided by equivalent rectangle short side. Median values of those two parameters are displayed in Table 3, both in numbers and surface. When only the number of particles is taken in account for the calculation of the median, the same importance is given to all the particles, independently of their size, resulting in a very low equivalent diameter in the case of samples containing dusts. Area-based distributions allow taking into account the particle sizes as their 2Dprojected area, given more importance to the biggest particles and thus resulting in a higher apparent size. Elongation (E) is the best morphological parameter to describe fibre aspect ratio $(\alpha)$, with the established relationship: $E=\alpha+\frac{1}{\alpha}$ (eq.4).

\section{Table 3.}


The median equivalent diameter of particles increased with torrefaction temperature up to $230^{\circ} \mathrm{C}$, from $197 \mu \mathrm{m}$ up to $401 \mu \mathrm{m}$ (in area-based distribution). At $280^{\circ} \mathrm{C}$ a particle size drop was noticed, reaching a size close to the raw WSF (Table 3). Regarding fibre aspect ratio, values of 2.8, 3.0, 3.5 and 2.7 were calculated from median elongation values (in area-based distribution) for WSF, WSF-t1, WSF-t4 and WSF-t6, respectively. Fibre aspect ratio followed the same evolution as median equivalent diameter. The increase of particle size and elongation for torrefaction conducted at $180^{\circ} \mathrm{C}$ and $230{ }^{\circ} \mathrm{C}$ could be related to the combustion of residual fine particles in WSF, thus leaving only biggest particles in the torrefied samples. This was confirmed by the increase of median equivalent diameter in number-based distribution (more impacted by the presence of fines in the sample). In the case of $280^{\circ} \mathrm{C}$-torrefied samples, the decrease of both median particle size and elongation could be ascribed to the degradation of fibres themselves (dehydration and depolymerisation of constituents), affecting their tips.

Based on these results, $230{ }^{\circ} \mathrm{C}$ was selected as being the highest torrefaction temperature - among those tested - before drastic fibre degradation, in terms of fibre weight loss, composition, size and morphology. For the rest of the study, conditions of $230^{\circ} \mathrm{C}$ during 45 minutes will be thus selected to produce torrefied fibres in a medium quantity (around 500g) in a pilot reactor for further composite preparation, and will be referred as WSF-t.

Microscopic appearance of torrefied fibres. The appearance of torrefied fibres (WSF-t) was observed by SEM and compared to untreated fibres (Figure 3). At low magnification, both samples displayed a similar appearance (Figure 3 A \& D) and the slight increase of elongation evaluated from morphological analysis for WSF-t was not so much visible on bigger fibres, which confirmed that the shift in elongation was due to the removal of poorly elongated particles, i.e. dust combustion, during torrefaction.

Zooming on fibres revealed differences of surface morphology (Figure 3 B, C, E \& F). Untreated fibres display a moderately rough surface, with residual dusts aggregated on big particles - as already suggested by morphology analysis - while torrefied fibres surface looks like an assembly of different tissues peeling off (Figure $3 \mathrm{E}$ ), tissues surface itself appearing very smooth on high magnification (Figure $3 \mathrm{~F}$ ). It is difficult to conclude how the observed differences of surface might impact further fibre/matrix adhesion. As regards to mechanical adhesion, rough surfaces would be preferred, since matrix would have more gripping possibilities, thus favouring mechanical interlocking. But it is possible that the observed differences of surface might not be sensitive enough, or that residual dusts aggregated on WSF big particles might be dragged away in polymer melt during extrusion.

\section{Figure 3.}

Wettability of torrefied fibres. Compared to lignocellulosic fibres, PHBV is considered as a hydrophobic material, which is confirmed by the weak polar component of its surface free energy and the water contact 
angle value (Table 4). Indeed, a water contact angle value higher than $90^{\circ}$ is given as a proof of hydrophobicity. The impact of torrefaction on the surface free energy of fibres was assessed in order to predict their respective affinity with the matrix. Fibre surface free energy was assessed through contact angle measurements (Table 4). As for all lignocellulosic fibres that are considered as hydrophilic by nature, the polar component of WSF ranged between 15 and $25 \mathrm{mN} \cdot \mathrm{m}^{-1}$, with a mean value of $23.4 \mathrm{mN} . \mathrm{m}^{-}$

${ }^{1}$. Torrefaction led to a significant increase in fibre hydrophobicity, as reflected by the increase of water contact angle value from $78^{\circ}$ up to $116^{\circ}$ and the increase of the surface energy dispersive component from 27.5 up to $41.8 \mathrm{mN} \cdot \mathrm{m}^{-1}$ (Table 4 ).

\section{Table 4.}

Such results were confirmed by dynamic vapour sorption measurements (Figure 4). For relative humidities higher than $20 \%$, moisture sorption of WSF-t was significantly lower than the one of untreated WSF. From those results, it can be predicted that WSF-t might display a better affinity with PHBV than WSF, thus leading to a better fibre/matrix adhesion. It is thus expected that mechanical properties of WSF-t-based composites will be positively influenced.

\section{Figure 4.}

\subsection{Impact of torrefied fibres on the structure and functional properties of composite materials}

Approximately 500g of WSF-t were prepared in a medium sized reactor, with the protocol set up in the previous part $\left(45 \mathrm{~min}\right.$ at $\left.230^{\circ} \mathrm{C}\right)$. They were then mixed with PHBV by melt-extrusion, with increasing fibre content from $10 \mathrm{wt} \%$ up to $30 \mathrm{wt} \%$. In order to better understand the relationships between the structure and the functional properties and the role of fibre torrefaction, all materials were analysed in two steps. First, their structure, through their morphology, molecular weight and crystallisation of PHBV, was assessed. Then, their functional properties, i.e. their mechanical and water vapour permeability, were evaluated and explained in relation to the obtained structure.

\subsubsection{Composites structure}

Fibre/matrix interactions. Table 4 presents the theoretical fibre/matrix work of adhesion $\left(\mathrm{W}_{12}\right)$, reflecting the thermodynamic work needed to separate both phases, and the interfacial tension $\left(\gamma_{12}\right)$ calculated for composites filled with either WSF or torrefied WSF from surface energy values. A higher fibre/matrix compatibility can be deduced from either a higher work of adhesion or a lower interfacial tension. Thus, it could be deduced from predictions that the torrefaction treatment allowed to significantly 
increase the affinity of fibres towards PHBV, with a work of adhesion of respectively 49.6 and 67.7 N.m-1 for WSF and WSF-t with PHBV.

Composite morphology. Differences in adhesion expected from contact angle measurements were further investigated by SEM observations. PHBV-based materials were cryo-fractured, and the surface of their cross-section was observed by scanning electron microscopy (Figure 5). As shown in previous studies, PHBV matrix displayed a smooth surface, with the presence of micro-crystals, which were ascribed to the presence of boron nitride as nucleating agent in this grade of PHBV.

In the case of composite materials filled with a fibre content up to $30 \mathrm{wt} \%$, fracture surfaces were rough and uneven, especially for untreated WSF-based composites, where pull-outs were visible. No fibre aggregate was detected for all studied samples. This could be supported by the fact that, for these filler contents, mechanical shearing forces induced during extrusion are sufficient to break potential fibre aggregates. Interfacial gaps have been noticed, again, especially wide for WSF (Figure 5F). WSF-t fibres were found to be quite well embedded within the PHBV matrix and smaller gaps were noticed at the fibre/matrix interface. These elements let assume a better fibre/matrix adhesion in the case of WSF-t, which should lead to a better preservation of resultant composites mechanical properties. Such an improvement would be ascribed to the increased hydrophobicity of torrefied fibres, as observed from contact angle measurements and DVS results, thus having a better affinity to interact with the PHBV matrix.

\section{Figure 5.}

Molecular weight. PHBV chains molecular weight was assessed by gel permeation chromato-graphy. Degradation of PHBV polymer was generally exacerbated in presence of fibres. No linear evolution of molecular weight was evidenced neither towards fibre content, nor fibre type. Polydispersity index was not much affected neither. As a conclusion, it can be asserted that torrefaction of fibre did not have a specific effect on resultant composites molecular weight evolution.

\section{Table 5.}

Crystallisation behaviour. Dynamical scanning calorimetry was used to assess the impact of fibre torrefaction on the melting and crystallization behaviours. Crystallinity, melting and crystallisation temperatures followed the same trend towards fibre content for both fibre types (Table 5). However, small difference of crystallisation temperature was observed for WSF-t-based materials, which presented a slightly better preserved crystallisation temperature. This might indicate that crystallisation was easier in PHBV-WSF-t composites. 


\subsubsection{Composite properties}

Mechanical properties. The same evolution of stress, strain at break and Young's modulus was reported for both untreated and torrefied fibres, in spite of the few difference of structure previously highlighted and especially an improved fibre/matrix adhesion in the case of torrefied fibres (Figure 6). Differences in Young's modulus and strain at break between WSF and WSF-t based composites became significant for high fibre contents (30 wt\%): PHBV-30WSF-t composites are more rigid than PHBV-30WSF. The increase of Young's modulus could be related to the apparent increase of aspect ratio of WSF-t, and maybe to an increased intrinsic rigidity of the fibre, induced by the torrefaction. For strain a break, a hypothesis could explain the results obtained here: the decrease of strain at break could be related to the fibre/matrix adhesion observed for WSF-t. Since natural fibres generally present poor strain at break themselves [1], a good fibre/matrix adhesion might restrain matrix intrinsic strain at break.

\section{Figure 6.}

Water vapour permeability. Water vapour permeability (WVP) of PHBV-based materials was assessed for increasing fibre content of torrefied fibres (Table 6). In a previous study [17], the introduction of wheat straw fibres led to an increase in the water vapour transmission rate (WVTR) of PHBV with increasing fibre content, and even more for increasing fibre size. This was ascribed to the hydrophilicity of wheat straw fibres that adsorbed much more water vapour than PHBV and to structural changes at either the macroscopic or (macro)molecular scale induced by the presence of wheat straw fibres, including the creation of a preferential pathway for the diffusion of water vapour at the fibre/matrix interface and the presence of little microscopic holes in the matrix. The increase in WVP with fibre content has been already reported by Ludueña et al. [27], who explained this effect by fibre agglomeration.

The opposite effect was displayed here for contents of WSF-t lower than $20 \mathrm{wt} \%$, with a significant decrease in WVP, until reaching almost 70\% of matrix' value for PHBV-20WSF-t. This decrease could be due to the hydrophobic nature of WSF-t, but more probably, to structural changes. Indeed, the popular hypothesis of tortuosity effect increased by fibre introduction could be applied, supporting a better fibre dispersion in the case of torrefied fibres. An improved fibre/matrix adhesion would also be in favour of a decrease in WVP since it would ensure that no gap, void or defect generally induced by the fibres, would create a preferential pathway. This corroborates the improved fibre/matrix adhesion suggested by SEM observations and prediction of works of adhesion from contact angles measurements.

For a fibre content of $30 \mathrm{wt} \%$, WVP of PHBV/WSF-t composites increased. It was likely that a percolation threshold might be achieved for a fibre content of $30 \mathrm{wt} \%$ due to favoured agglomeration of fibres, thus favouring the transfer of water vapour through wheat straw fibres. 
Table 6.

\section{Conclusion}

Different torrefaction temperatures and durations were applied to wheat straw fibres (WSF), aiming at the preparation of fillers for composite applications. No significant impact of torrefaction duration was evidenced while increasing torrefaction temperature up to $280^{\circ} \mathrm{C}$ significantly impacted fibre composition, colour, morphology and hydrophobicity. Composition remained almost constant until $280^{\circ} \mathrm{C}$, temperature at which cellulose content was drastically decreased. Fibres darkened gradually, until reaching a black colour for a thermal treatment at $280^{\circ} \mathrm{C}$. Morphology analysis revealed an apparent increase of size and aspect ratio for samples torrefied at 180 and $230^{\circ} \mathrm{C}$, which was related to the combustion of dust particles. Torrefaction enabled to hydrophobize wheat straw fibres, as reflected by a water contact angle value higher than $90^{\circ}$ and an increase in the dispersive component of the surface free energy. Based on these elements and process yield, a torrefaction protocol was chosen, i.e. $45 \mathrm{~min}$ at $230^{\circ} \mathrm{C}$, in order to prepare a large amount of torrefied fibres for further use as filler in PHBV-based composites.

A better fibre/matrix adhesion was spotted in the case of composites containing torrefied fibres, while PHBV molecular weight and crystallinity were not significantly affected. As regards to functional properties, echoing the few difference of structure evidenced for increasing fibre content, a similar evolution in mechanical properties was reported for both untreated and torrefied fibres for fibre contents up to $20 \mathrm{wt} \%$. It was concluded that improving fibre/matrix adhesion and increasing fibre aspect ratio did not lead to a better preservation of mechanical properties, due to the inevitable presence of microscopic defects in the composite materials. Only a slight increase in rigidity was noticed for materials filled with $30 \mathrm{wt} \%$ of torrefied fibres.

As regards water vapour permeability (WVP), a 30\% decrease was first noticed for torrefied fibre contents up to $20 \mathrm{wt} \%$, whereas an increase in WVP was previously reported for untreated fibres. This was ascribed to the hydrophobic nature of fibres and more probably, to structural changes including a classical tortuosity effect and an improved fibre/matrix adhesion. WVP then increased for a fibre content of $30 \mathrm{wt} \%$, probably due to percolation threshold crossing.

\section{Acknowledgements}

This work was carried out in the framework of the EcoBioCAP project, which is supported by the European Commission through the Seventh Framework for Research \& Technological Development 
(FP7/2011-2015) under the Grant Agreement FP7-265669. Besides, authors thank Laetitia Contant and Emilie Thomas for technical support.

\section{References}

[1] Faruk O, Bledzki A, Fink HP, Sain M. Biocomposites reinforced with natural fibers: 2000-2010. Prog Polym Sci 2012;37:1552-96.

[2] Satyanarayana KG, Arizaga GGC, Wypych F. Biodegradable composites based on lignocellulosic fibers - An overview. Prog Polym Sci 2009;34:982-1021.

[3] Bledzki AK, Gassan J. Composites reinforced with cellulose based fibres. Prog Polym Sci 1999;24:221-74.

[4] Mohanty A, Misra M, Drzal LT. Surface modifications of natural fibres and performance of the resulting biocomposites : an overview. Compos Interface 2001;8:313-343.

[5] George J, Sreekala MS, Thomas S. A review on interface modification and characterization of natural fibre reinforced plastic composites. Polym Eng Sci 2001;41(9):1471-85.

[6] Belgacem MN, Gandini A. The surface modification of cellulose fibres for use as reinforcing elements in composite materials. Composite Interfaces 2005;12(1-2):41-75.

[7] Gandini A, Belgacem MN. Physical \& chemical methods of fiber surface modification. In: Zafeiropoulos $\mathrm{E}$, editor. Interface engineering in natural fibre composites for maximum performance. Cambridge (UK): Woodhead Publishing Limited, 2011, p.3-42.

[8] Commandré J-M, LêThánh K, Leboeuf A, Rousset P. Volatile Yields and Solid Grindability after Torrefaction of Various Biomass Types, TCBiomass 2013, Chicago.

[9] Nocquet T, Dupont C, Commandre J-M., Grateau M, Thiery S, Salvador S. Volatile species release during torrefaction of wood and its macromolecular constituents: Part 1 - Experimental study. Energy 2014;72:180-187.

[10] Arias B, Pevida C, Fermoso J, Plaza MG, Rubiera F, Pis JJ. Influence of torrefaction on the grindability and reactivity of woody biomass. Fuel Process Technol 2008;89:169-175. 
[11] Bridgeman TG, Jones JM, Shield I, Williams PT. Torrefaction of reed canary grass, wheat straw and willow to enhance solid fuel qualities and combustion properties. Fuel 2008;87(6):844-56.

[12] Phanphanich M, Mani S. Impact of torrefaction on the grindability and fuel characteristics of forest biomass. Bioresource Technol 2011;102:1246-53.

[13] Serafim LS, Lemos PC, Albuquerque MGE, Reis MAM. Strategies for PHA production by mixed cultures and renewable waste materials. Appl Microbiol Biotechnol 2008;81:615-628.

[14] Avella M, La Rota G, Martuscelli E, Raimo M, Sadocco P, Elegir G, Riva R. Poly(3hydroxybutyrate-co-3-hydroxyvalerate) and wheat straw fibre composites: thermal, mechanical properties and biodegradation behaviour. J Mater Sci, 2000;35:829-836.

[15] Ahankari SS, Mohanty AK, Misra M. Mechanical behavior of agro-residue reinforced poly(3 hydroxybutyrate-co-3-hydroxyvalerate) (PHBV) green composites: A comparison with traditional polypropylene composites. Comp Sci Technol, 2011;71:653-7.

[16] Berthet MA, Angellier-Coussy H, Staebler A, Vicente A, Hilliou L, Gontard N. Exploring the potentialities of using lignocellulosic fibres derived from three food by-products as constituents of biocomposites for food packaging. Ind Crop Prod 2015;69:110-122.

[17] Berthet MA, Angellier-Coussy H, Chea V, Guillard V, Gastaldi E, Gontard N. Sustainable food packaging: Valorising wheat straw fibres for tuning PHBV-based composites properties. Compos Part AAppl S 2015;72:139-147.

[18] Shang L, Ahrenfeldt J, Holm JK, Sanadi AR, Barsberg S, Thomsen T, Stelte W, Henriksen UB. Changes of chemical and mechanical behavior of torrefied wheat straw. Biomass Bioenergy 2012;40:6370.

[19] Pasangulapati V, Ramachandriya KD, Kumar A, Wilkins MR, Jones CL, Huhnke RL. Effects of cellulose, hemicellulose and lignin on thermochemical conversion characteristics of the selected biomass. Bioresource Technol 2012;114:663-669.

[20] Monties B. Dosage de la lignine insoluble en milieu acide : influence du prétraitement par hydrolyse acide sur la lignine Klason de bois et de paille. Agronomie 1984;4:387-392 
[21] Montaño-Leyva B, Silva GGD, Gastaldi E, Torres-Chavez P, Gontard N, Angellier-Coussy H. Biocomposites from wheat proteins and fibres: structure/mechanical properties relationships. Ind Crop Prod 2013;43:545-55.

[22] Owens DK, Wendt RC. Estimation of the surface free energy of polymers. J Appl Polym Sci 1969;13:1741-47.

[23] Guillard V, Broyart B, Bonazzi C, Guilbert S, Gontard N. Moisture diffusivity in sponge cake as related to porous structure evaluation and moisture content. J Food Sci 2003;68:555-562.

[24] Barham PJ, Keller A, Otun EL, Holmes PA. Crystallization and morphology of a bacterial thermoplastic: poly-3-hydroxybutyrate. J Mater Sci 1984;19:2781-94.

[25] Chen WH, Kuo PC. A study on torrefaction of various biomass materials and its impact on lignocellulosic structure simulated by a thermogravimetry. Energy 2010;35:2580-86.

[26] Pelaez-Samaniego MR, Yadama V, Garcia-Perez ., Lowell E, McDonald AG. Effect of temperature during wood torrefaction on the formation of lignin liquid intermediates. J Anal Appl Pyrol 2014;109:222233.

[27] Ludueña L, Vázquez A, Alvarez V. Effect of lignocellulosic filler type and content on the behavior of polycaprolactone based eco-composites for packaging applications. Carbohydr Polym 2012;87:411-421. 


\section{Figure captions.}

Figure 1. Thermogravimetric analysis of wheat straw fibres under inert atmosphere $\left(10^{\circ} \mathrm{C} \cdot \mathrm{min}^{-1}\right)$ for different torrefaction temperature and duration conditions.

Figure 2. Visual aspect and colour attributes $\left(\mathrm{L}^{*}, \mathrm{a}^{*}\right.$ and $\left.\mathrm{b}^{*}\right)$ of samples for different torrefaction temperature and duration conditions.

Figure 3. SEM pictures of untreated wheat straw fibres (A, B \& C) and torrefied wheat straw fibres (D, E $\& \mathrm{~F})$.

Figure 4. Water vapour sorption isotherms of WSF $(\Delta)$ and WSF-t ( - ) (vertical bars standing for the experimental error are two weak to be visible on the graph).

Figure 5. SEM pictures of the PHBV matrix alone (A, B \& C) and PHBV composites containing $20 \mathrm{wt} \%$ of untreated (WSF) (D, E \& F) and torrefied (WSF-t) wheat straw fibres (G, H \& I).

Figure 6. Tensile tests results, i.e. stress $(\sigma)$ and strain $(\varepsilon)$ at break, Young's modulus $(E)$ and energy at break (EB), normalized towards respective control, for PHBV-based composites for non torrefied (WSF) and torrefied wheat straw fibres (WSF-t). 
Figure 1, Berthet et al.

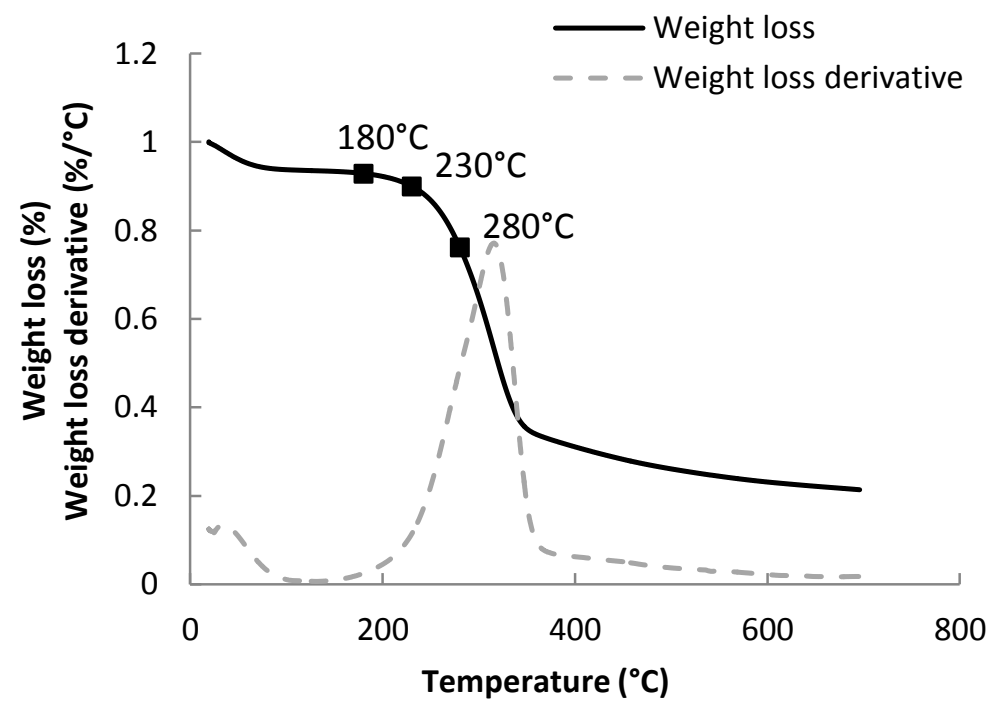


Figure 2, Berthet et al.

\begin{tabular}{|c|c|c|c|c|c|c|c|}
\hline Sample & WSF & WSF-t1 & WSF-t2 & WSF-t3 & WSF-t4 & WSF-t5 & WSF-t6 \\
\hline Temperature & - & $180^{\circ} \mathrm{C}$ & $180^{\circ} \mathrm{C}$ & $230^{\circ} \mathrm{C}$ & $230^{\circ} \mathrm{C}$ & $280^{\circ} \mathrm{C}$ & $280^{\circ} \mathrm{C}$ \\
\hline Duration & - & $45 \min$ & $90 \mathrm{~min}$ & $15 \mathrm{~min}$ & $45 \mathrm{~min}$ & $15 \mathrm{~min}$ & $45 \mathrm{~min}$ \\
\hline $\begin{array}{l}\text { Visual } \\
\text { aspect }\end{array}$ & & & & & & & \\
\hline$L^{*}$ & $70 \pm 2$ & $65 \pm 3$ & $65 \pm 1$ & $52 \pm 2$ & $51 \pm 1$ & $45 \pm 3$ & $42 \pm 3$ \\
\hline$a^{*}$ & $9.1 \pm 0.2$ & $8.0 \pm 0.3$ & $7.6 \pm 0.3$ & $5.3 \pm 0.3$ & $5.7 \pm 0.4$ & $2.8 \pm 0.2$ & $2.3 \pm 0.3$ \\
\hline$b^{*}$ & $17.9 \pm 0.9$ & $15.5 \pm 0.6$ & $12.9 \pm 0.9$ & $3.2 \pm 0.7$ & $3.7 \pm 0.8$ & $-2.1 \pm 0.1$ & $-2.8 \pm 0.7$ \\
\hline
\end{tabular}


Figure 3, Berthet et al.
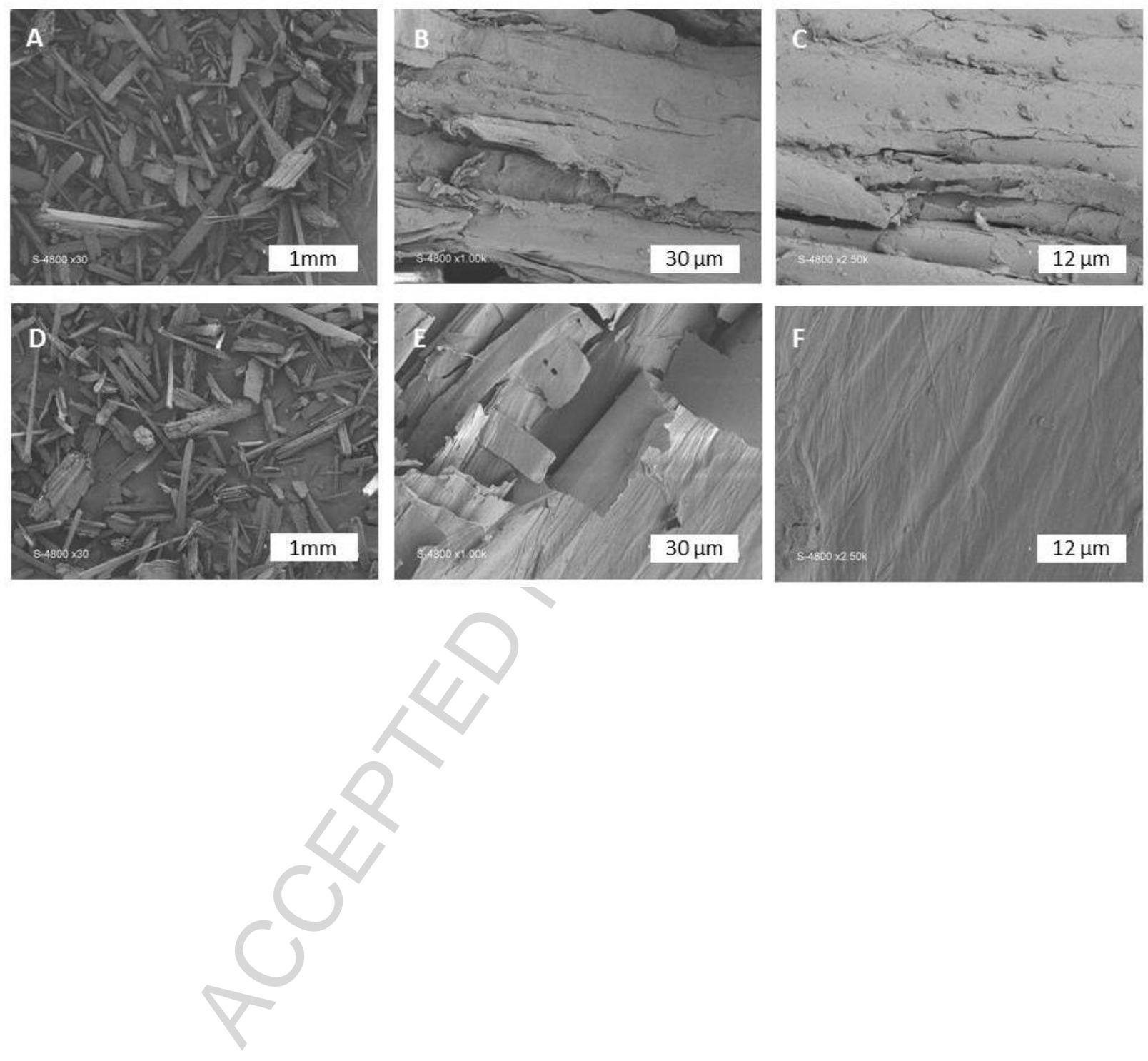
Figure 4, Berthet et al.

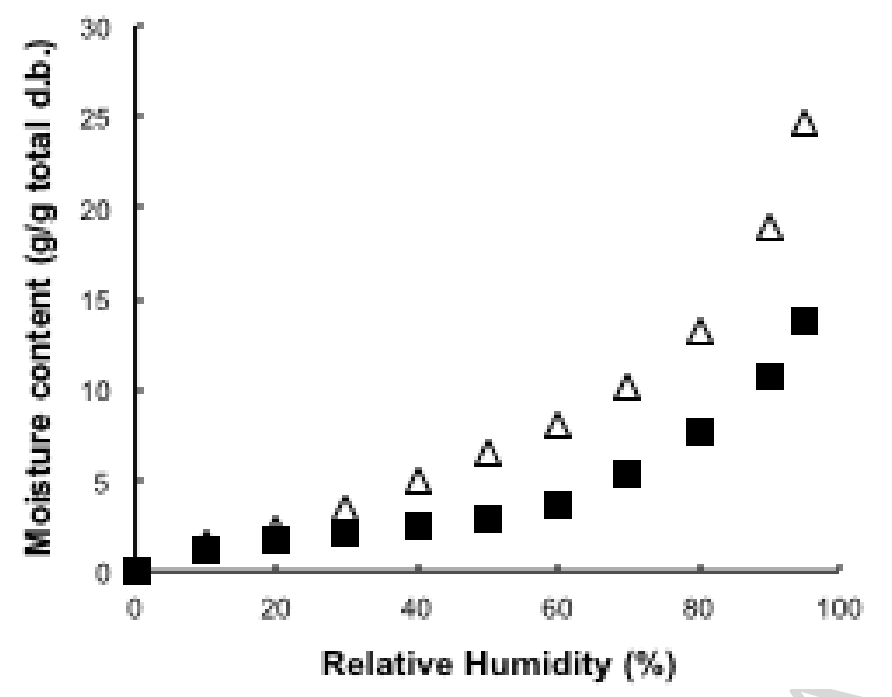


Figure 5, Berthet et al.

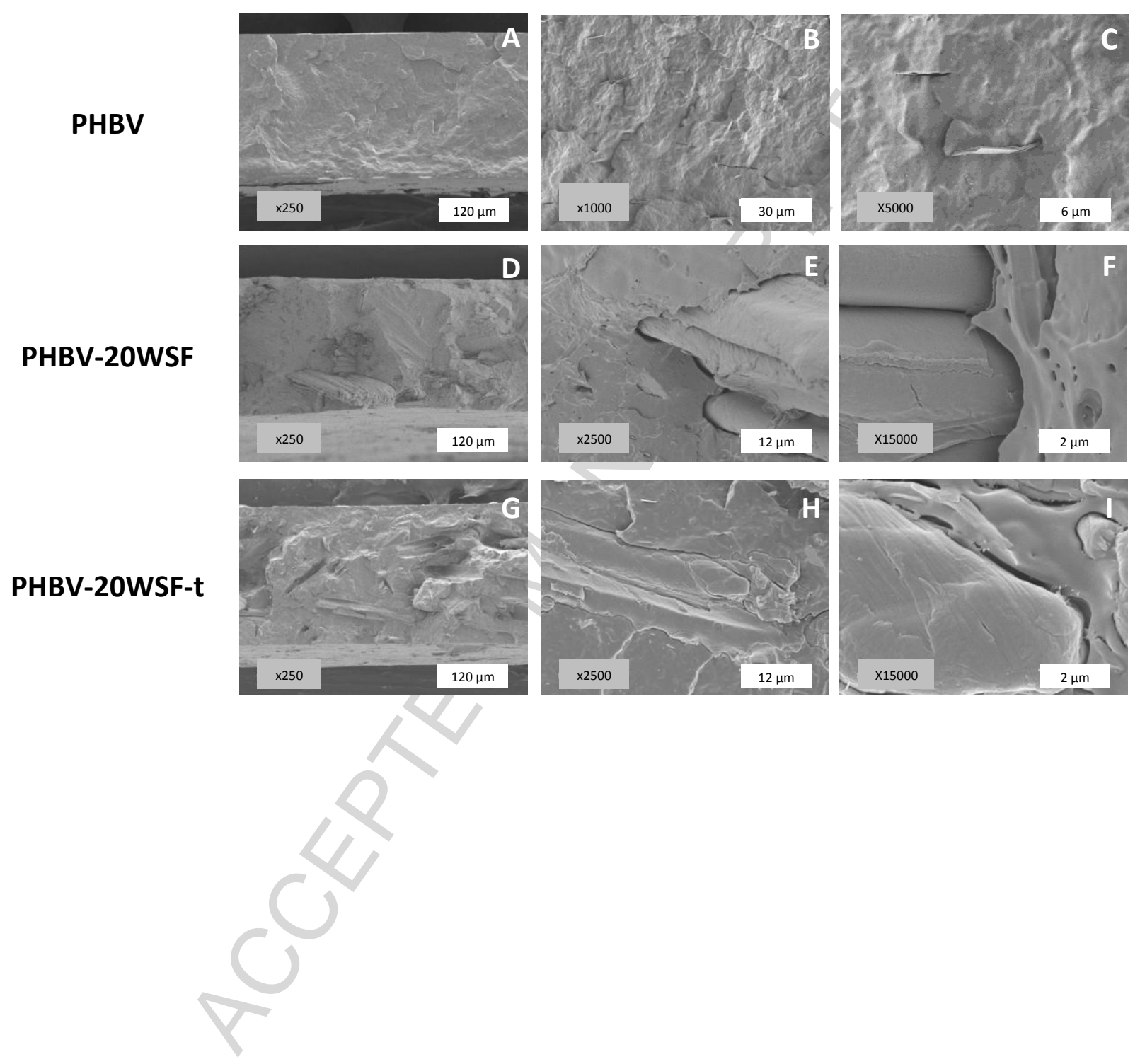


Figure 6, Berthet et al.
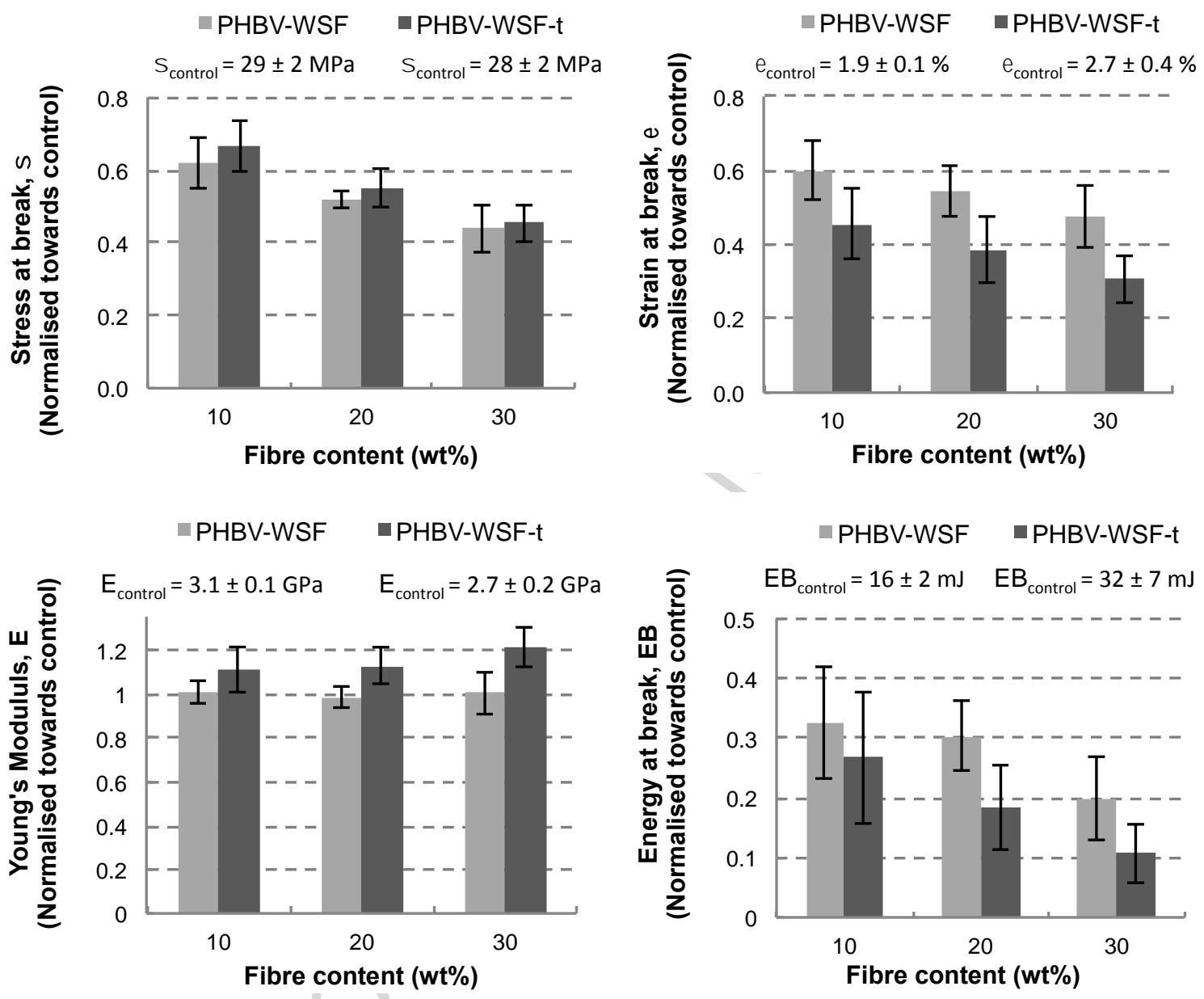
Table 1. Fibre weight yield (in wt\%) for different temperature and duration of torrefaction.

\begin{tabular}{cccc}
\hline Temperature & $\mathbf{1 8 0}^{\circ} \mathbf{C}$ & $\mathbf{2 3 0}^{\circ} \mathbf{C}$ & $\mathbf{2 8 0}^{\circ} \mathbf{C}$ \\
\hline Duration & - & $82.3 \pm 0.5$ & $52.2 \pm 3.3$ \\
$\mathbf{1 5}$ min & $93.3 \pm 0.6$ & $82.2 \pm 0.2$ & $45.1 \pm 1.8$ \\
$\mathbf{4 5}$ min & $94.0 \pm 0.1$ & - & - \\
\hline $\mathbf{9 0}$ min & &
\end{tabular}


Table 2. Composition of WSF and torrefied wheat straw fibres, normalized for each fibre type (d.b.), for increasing torrefaction temperature and duration.

\begin{tabular}{cccccccc}
\hline $\begin{array}{c}\text { Sample } \\
\text { name }\end{array}$ & $\begin{array}{c}\text { Torrefaction } \\
\text { temperature } \\
\left({ }^{\circ} \mathbf{C}\right)\end{array}$ & $\begin{array}{c}\text { Torrefaction } \\
\text { duration } \\
(\mathbf{m i n})\end{array}$ & $\begin{array}{c}\text { Cellulose } \\
\mathbf{( w t \% )}\end{array}$ & $\begin{array}{c}\text { Hemicelluloses } \\
(\mathbf{w t} \%)\end{array}$ & $\begin{array}{c}\text { Lignin } \\
(\mathbf{w t} \%)\end{array}$ & $\begin{array}{c}\text { Ashes } \\
(\mathbf{w t} \%)\end{array}$ & $\begin{array}{c}\text { Others } \\
(\mathbf{w t} \%)\end{array}$ \\
\hline WSF & - & - & $42.2 \pm 12.8$ & $7.9 \pm 0.8$ & $27.6 \pm 1.7$ & $5.3 \pm 0.4$ & $16.9 \pm 8.9$ \\
\hline WSF -t1 & 180 & 45 & $47.2 \pm 3.9$ & $9.3 \pm 0.7$ & $21.9 \pm 9.6$ & $5.7 \pm 0.1$ & $15.9 \pm 9.5$ \\
\hline WSF -t2 & 180 & 90 & $41.2 \pm 2.7$ & $7.1 \pm 1.9$ & $23.2 \pm 3.8$ & $5.6 \pm 0.1$ & $22.9 \pm 11.5$ \\
\hline WSF -t3 & 230 & 15 & $48.8 \pm 7.9$ & $5.0 \pm 0.8$ & $27.8 \pm 0.3$ & $6.4 \pm 0.1$ & $11.9 \pm 3.9$ \\
\hline WSF -t4 & 230 & 45 & $46.8 \pm 4.9$ & $3.4 \pm 1.1$ & $30.3 \pm 8.4$ & $6.4 \pm 0.1$ & $13.1 \pm 9.1$ \\
\hline WSF -t5 & 280 & 15 & $8.0 \pm 3.7$ & $6.1 \pm 0.8$ & $59.1 \pm 6.7$ & $10.1 \pm 0.7$ & $16.7 \pm 12.9$ \\
\hline WSF -t6 & 280 & 45 & $2.3 \pm 0.2$ & $10.9 \pm 0.6$ & $61.4 \pm 3.0$ & $11.7 \pm 0.5$ & $13.8 \pm 3.4$ \\
\hline
\end{tabular}


Table 3. Morphology analysis results for untreated fibres (WSF) and fibres with increasing torrefaction temperature, for a residence time of $\mathbf{4 5} \mathrm{min}$

\begin{tabular}{|c|c|c|c|c|c|}
\hline & & \multicolumn{2}{|c|}{ Area-based distribution } & \multicolumn{2}{|c|}{ Number-based distribution } \\
\hline & & $\begin{array}{c}\text { Equivalent } \\
\text { diameter }^{\mathrm{a}} \\
(\mu \mathrm{m})\end{array}$ & Elongation $^{b}$ & $\begin{array}{c}\text { Equivalent } \\
\text { diameter }^{\mathrm{a}} \\
(\mu \mathrm{m})\end{array}$ & Elongation $^{b}$ \\
\hline \multirow[t]{2}{*}{ WSF } & median & 197 & 3.2 & 3 & 1.8 \\
\hline & $\operatorname{span}^{c}$ & 0.8 & 1.5 & 0.9 & 0.4 \\
\hline WSF-t1 & median & 313 & 3.4 & 37 & 2.6 \\
\hline$\left(180^{\circ} \mathrm{C}\right)$ & $\operatorname{span}^{c}$ & 0.9 & 1.5 & 6.7 & 1.2 \\
\hline WSF-t4 & median & 401 & 3.8 & 28 & 2.2 \\
\hline$\left(230^{\circ} \mathrm{C}\right)$ & span $^{c}$ & 1.3 & 1.2 & 8.1 & 1.1 \\
\hline WSF-t6 & median & 239 & 3.1 & 23 & 2.3 \\
\hline$\left(280^{\circ} \mathrm{C}\right)$ & $\operatorname{span}^{c}$ & 1.6 & 1.4 & 4.9 & 0.9 \\
\hline
\end{tabular}

${ }^{a}$ Diameter of a circle with the same area.

${ }^{\mathrm{b}}$ Max Feret diameter divided by equivalent rectangle short side.

${ }^{\mathrm{c}}$ Difference between the $90^{\text {th }}$ and $10^{\text {th }}$ percentiles divided by the median value. 
Table 4. Contact angle values $\left(^{\circ}\right)$ of liquids of reference on PHBV and fibres, total surface energy $(\gamma)$, polar and dispersive components (respectively $\gamma_{\mathrm{s}}{ }^{\mathrm{p}}$ and $\left.\gamma_{\mathrm{s}}{ }_{\mathrm{s}}\right)$, and work of adhesion $\left(\mathrm{W}_{12}\right)$ and interfacial tension $\left(\gamma_{12}\right)$ between fibres and PHBV.

\begin{tabular}{|c|c|c|c|c|c|c|c|c|c|}
\hline & Water & Glycerol & $\begin{array}{c}\text { Ethylene } \\
\text { Glycol }\end{array}$ & $\begin{array}{l}\text { Diiodo- } \\
\text { methane }\end{array}$ & $\begin{array}{c}\gamma_{\mathrm{s}} \\
\left(\mathbf{m N} \cdot \mathrm{m}^{-1}\right)\end{array}$ & $\begin{array}{c}\gamma_{s}^{p} \\
\left(m N^{p} \cdot m^{-1}\right)\end{array}$ & $\begin{array}{c}\gamma_{s}^{d} \\
\left(m N^{d} \cdot m^{-1}\right)\end{array}$ & $\begin{array}{c}W_{12} \\
\left(m N^{-1} m^{-1}\right)\end{array}$ & $\left.\gamma_{12} \underset{1}{(\mathrm{mNN}}\right)$ \\
\hline PHBV & $100 \pm 2$ & $93 \pm 4$ & $80 \pm 7$ & $61 \pm 3$ & $27.8 \pm 3.1$ & $0.5 \pm 0.3$ & $27.3 \pm 3.1$ & - & - \\
\hline WSF & $33 \pm 5$ & $91 \pm 2$ & $48 \pm 3$ & $48 \pm 3$ & $44.5 \pm 0.5$ & $23.4 \pm 0.6$ & $21.1 \pm 4.5$ & $49.6 \pm 1.5$ & $22.7 \pm 1.1$ \\
\hline WSF-t & $116 \pm 1$ & $111 \pm 1$ & $62 \pm 1$ & $37 \pm 2$ & $44.1 \pm 1.4$ & $2.3 \pm 0.4$ & $41.8 \pm 1.1$ & $67.7 \pm 0.7$ & $4.2 \pm 0.3$ \\
\hline
\end{tabular}


Table 5. Molecular weight $\left(M_{w}\right)$ with polydispersity index $\left(I_{p}\right)$ and DSC results: melting temperature (Tm), crystallisation temperature (Tc) and crystallinity for control PHBV and PHBV-based composites filled with untreated (WSF) and torrefied wheat straw fibres (WSF-t)

\begin{tabular}{cccccc}
\hline & $\mathbf{M}_{\mathbf{w}}(\mathbf{D a})$ & $\mathbf{I}_{\mathbf{p}}$ & $\mathbf{T m}\left({ }^{\circ} \mathbf{C}\right)$ & $\mathbf{T c}\left({ }^{\circ} \mathbf{C}\right)$ & $\begin{array}{c}\text { Cristallinity } \\
(\mathbf{\%})\end{array}$ \\
\hline PHBV control (WSF) & 231301 & 2.4 & $171.9 \pm 0.1$ & $121.8 \pm 0.2$ & $61.9 \pm 0.1$ \\
PHBV-10WSF & 203095 & 2.2 & $169.6 \pm 0.1$ & $118.3 \pm 0.4$ & $61.9 \pm 0.1$ \\
PHBV-20WSF & 197950 & 2.2 & $167.8 \pm 0.4$ & $115.8 \pm 0.1$ & $64.8 \pm 0.1$ \\
PHBV-30WSF & 235735 & 2.2 & $168.7 \pm 0.2$ & $115.8 \pm 0.1$ & $60.2 \pm 0.3$ \\
\hline \hline PHBV control (WSF-t) & 219945 & 2.2 & $173.2 \pm 0.3$ & $121.8 \pm 0.1$ & $63.4 \pm 0.2$ \\
PHBV-10WSF-t & 232957 & 2.3 & $171.5 \pm 0.1$ & $119.8 \pm 0.1$ & $63.8 \pm 0.2$ \\
PHBV-20WSF-t & 212343 & 2.1 & $170.4 \pm 0.1$ & $117.3 \pm 0.2$ & $64.1 \pm 0.4$ \\
PHBV-30WSF-t & 199656 & 2.1 & $170.4 \pm 0.6$ & $116.6 \pm 0.5$ & $60.6 \pm 0.6$ \\
\hline
\end{tabular}


Table 6. Water vapour transmission rate (WVTR) and permeability (WVP) of PHBV films with increasing torrefied fibre (WSF-t) content.

\begin{tabular}{|c|c|c|}
\hline & $\begin{array}{c}\text { WVTR } \\
\text { (g/(m2.day)) }\end{array}$ & $\begin{array}{c}\text { WVP } \\
\left(\times 10^{13} \mathrm{~mol} . \mathrm{m} /(\mathrm{m} 2 . s . P a)\right)\end{array}$ \\
\hline $\begin{array}{c}\text { PHBV } \\
\text { (control WSF-t) }\end{array}$ & $9.5 \pm 1.2$ & $6.6 \pm 0.8$ \\
\hline PHBV-10WSF-t & $7.3 \pm 1.5$ & $5.9 \pm 1.1$ \\
\hline PHBV-20WSF-t & $6.8 \pm 1.3$ & $4.9 \pm 0.4$ \\
\hline PHBV-30WSF-t & $13.8 \pm 1.0$ & $11.0 \pm 4.7$ \\
\hline
\end{tabular}




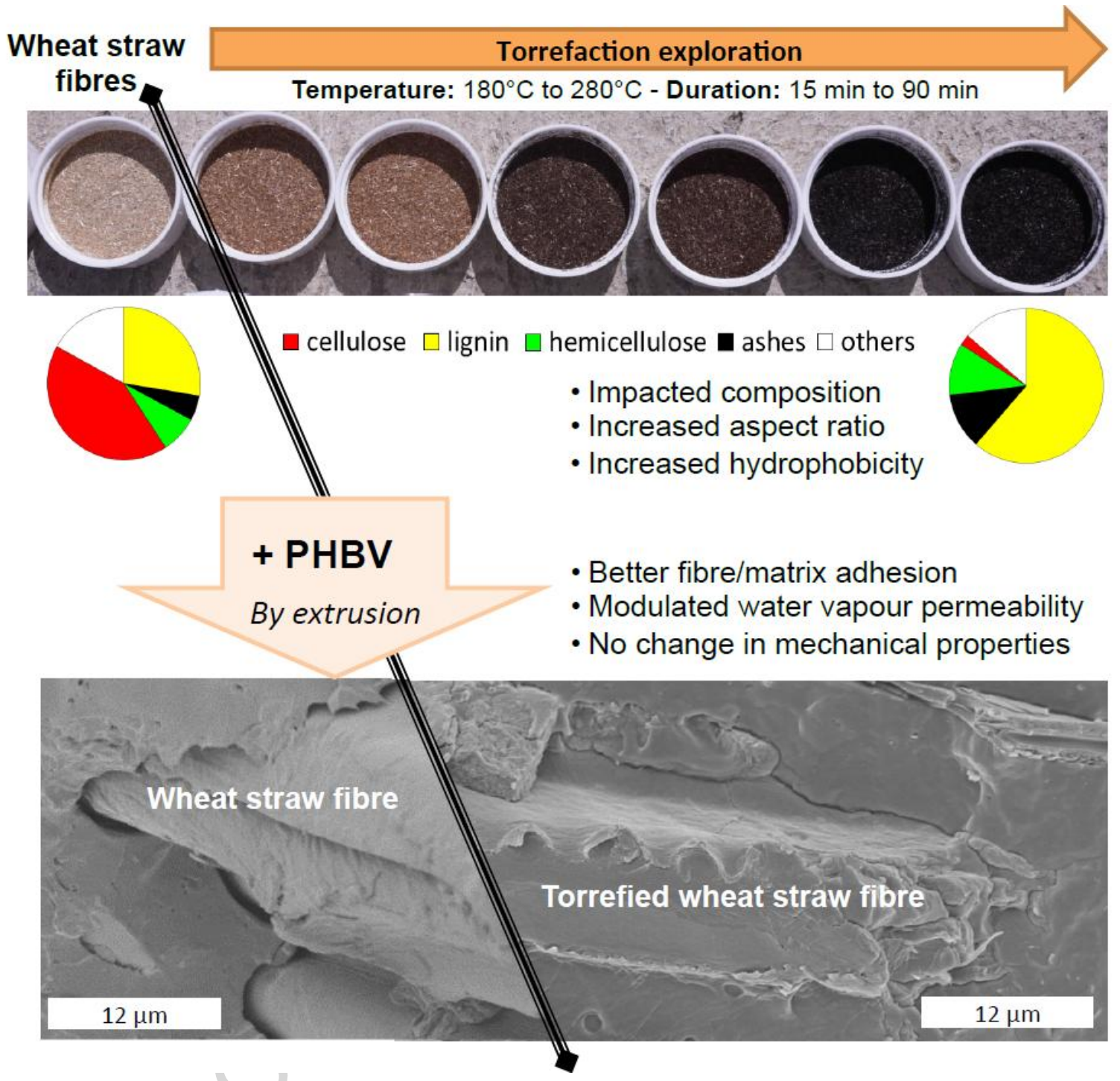

Graphical Abstract 


\section{Highlights}

- A torrefaction treatment was used to hydrophobize wheat straw fibres.

- An improved fibres/PHBV interfacial adhesion was obtained after fibre torrefaction.

- Mechanical properties of biocomposites were not impacted by fibre torrefaction.

- Water vapour permeability of biocomposites was modulated by using torrefied fibres. 